Munene Mwaniki

Wits School of Education, Visiting Associate, Hub for Multilingual Education and Literacies (HuMEL), University of the

Witwatersrand. E-mail: munene.mwaniki@wits. ac.za

DOI: https://dx.doi. org/10.18820/24150509/ JCH43.v1.11

ISSN 0258-2422 (Print) ISSN 2415-0509 (Online) Journal for Contemporary History

2018 43(1):215-241

(c) UV/UFS

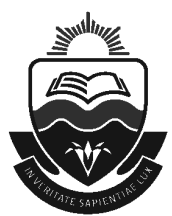

\section{LANGUAGE POLITICS AND THE STRUGGLE FOR THE SOUL OF THE UNIVERSITY OF THE FREE STATE (UFS): A MICROCOSM OF THE SOCIO-POLITICAL AND ECONOMIC STRUGGLES IN THE FREE STATE PROVINCE THROUGH TIME}

\begin{abstract}
For the better part of the last century the University of the Free State (UFS) - as the "most prestigious" higher education institution in the province - has been a key site for institutional language politics in the province. This brand of institutional language politics has been characterised by several contestations and permutations which can symbolically be described as a struggle for the soul of the UFS because of its far-reaching implications on UFS's "curriculum as institution" and linguistic culture. Four critical junctures have defined UFS's language politics over the last century. After a detailed characterisation of these critical junctures, the article argues and demonstrates that the contestations and permutations that have characterised institutional language politics at the UFS are a microcosm of the socio-political and economic struggles in the Free State Province through time, because of the centrality of the UFS in socio-political and economic discourses and dynamics of the province.
\end{abstract}

Keywords: Language politics; University of the Free State (UFS); curriculum as institution; linguistic culture; socio-political and economic struggles; critical junctures; Free State Province.

Sleutelwoorde: Taalpolitiek; Universiteit van die Vrystaat (UV); kurrikulum as instelling; taalkultuur; sosio-politieke en ekonomiese stryd; kritieke tydstip; Vrystaat-provinsie.

\section{INTRODUCTION}

The article interrogates two least-researched areas in educational and social sciences. The first one is the history of universities as a genre'. The second is the historiography

1 BL Strydom, Broad South Africanism and higher education: The Transvaal University College (1908 - 1919) (PhD, University of Pretoria, 2013), pp. 1-29. 
of sociology and politics of university language policies ${ }^{2}$. While the latter is virtually non-existent in the research literature,$^{3}$ a leitmotif that runs through the former is a revisionist historical streak imbued with an adulatory characterisation of Europe as the birthplace of the university ${ }^{4}$ - in line with the construct of Eurocentrism ${ }^{5}$. Material historical facts, however, bear out that the oldest universities in the world were established in Africa in the $9^{\text {th }}$ century $A D,{ }^{6}$ as well as the $10^{\text {th }}$ century $A D,{ }^{7}$ only to be followed by the establishment of universities in Europe in the $11^{\text {th }}$ century ${ }^{8}$ and the $12^{\text {th }}$ century. ${ }^{9}$ This aside however, "the modern university, with its mix of teaching and research functions, was the brainchild of the Prussian educational philosopher Wilhelm von Humboldt. In 1810 , he became the founding father of the University of Berlin, which put into practice his ideas and became a model for other universities in Europe and the United States. For almost 600 years, universities had served as little more than training grounds for lawyers, clerics, and other professionals. Humboldt changed all that by making research a vital complement of teaching, by emphasising science, by urging traffic across disciplinary boundaries, and by attempting to make the university contribute more directly to economy and society. He changed the terms of the discourse, and universities have been adapting and

2 A comprehensive overview of linguistic historiography is $\mathrm{K}$ Koerner (ed.), Practicing linguistic historiography: Selected essays (Amsterdam/Philadelphia: John Benjamins Publishing Company, 1989). However, this overview does not venture onto the terrain of sociology and politics of language historiography, or historiography of university language policies.

3 This is to the best of the knowledge of the researcher.

4 H Perkin, "History of universities". In: JJF Forest and PG Altbach (eds), International handbook of higher education (Dordrecht: Springer, 2007), p. 159.

5 S Amin, Eurocentrism - Modernity, religion, and democracy: A critique of Eurocentrism and culturalism, $2^{\text {nd }}$ Edition (Nairobi: Pambazuka Press, 2009), pp. 177-178. Also see, SJ Ndlovu-Gatsheni, "The entrapment of Africa within the global colonial matrices of power: Eurocentrism, coloniality, and deimperialization in the twenty-first century", Journal of Developing Societies 29(4), 2013, pp. 331-353; JM Blaut, The colonizer's model of the world: Geographical diffusionism and Eurocentric history (New York and London: The Guilford Press, 1993), p. 1; JM Blaut, Eight Eurocentric historians (New York and London: The Guilford Press, 2000); TG Wiley, "The lessons of historical investigation: Implications for the study of language policy and planning". In: T Ricento (ed.), An introduction to language policy: Theory and method (Malden: Blackwell Publishing, 2006), p. 141.

6 The University of Al-Karaouine in Fes, Morocco was established in 859 AD. It is recognised by the United Nations Educational, Scientific and Cultural Organisation (UNESCO) and the Guinness World Records as the oldest existing, continually operating and the first degree awarding educational institution in the world, according to Wikipedia.

7 Al-Azhar University in Cairo was established in 972 AD. It is Egypt's oldest degreegranting university and is renowned as Sunni Islam's most prestigious university, according to Wikipedia.

8 The University of Bologna was established in 1088.

9 The University of Paris (later associated with the Sorbonne) was established around 1150 , and the University of Oxford was established in 1167, according to Wikipedia. 
assimilating the model he espoused ever since. The university's role imparting higher education is straightforward and consistently reiterated. The two additional roles it acquired post-Humboldt - that of conducting basic research to advance knowledge and that of contributing to the development and assimilation of technology for civilian and military uses - have been adopted partially and unevenly over time and among countries by a few elite universities. Generally, basic research has appeared to be a more logical extension of teaching activities and one favoured by the academic mindset. Applied science for the purpose of devising commercial technologies has had a more uneven passage. It has been decried as a digression, possibly a distraction, and arguably inimical to the central role of the university, which is to teach." ${ }^{10}$ In a seminal treatise, Ernest Boyer collaborates this characterisation of the nature of the modern university by specifying that universities should pursue four types of scholarship; these being scholarship of discovery, integration, application and teaching. ${ }^{11}$ Whether the University of the Free State (UFS) has steadfastly exhibited fidelity to these core tenets since its establishment, is a matter that is open to persuasive critique, especially when the university's complicity in furthering the Afrikaner nationalist project for the better part of the $20^{\text {th }}$ century is brought to bear on the storied evolution of this institution. However, what is rather straightforward is the material fact that the institution - as a premier institution in the Free State Province for over a century - has been a site in which socio-political and economic struggles in the Free State Province and the South African society have played out to a large and substantial extent, respectively. To provide perspective to this assertion, it is important to outline, albeit briefly, the evolution of the university ${ }^{12}$ in South African society - historically.

Sehoole provides one of the most comprehensive overviews of the evolution of universities in South Africa. According to Sehoole, "the first institutions of higher education in South Africa emerged during the mid-19 century, with the establishment of two colleges, the South African College in Cape Town in 1829 and Victoria College in Stellenbosch in 1865, followed by the University of the Cape of Good Hope - the first South African university in 1873. Rhodes University followed in 1904 and in 1918, the South African College and Victoria College changed their names to the Universities of Cape Town and Stellenbosch, respectively. The University of the Cape of Good Hope became known as the University of South Africa (UNISA). The establishment of these universities in the southern part of the country could be linked to the

10 S Yusuf, "University-industry links: Policy dimensions". In: S Yusuf and K Nabeshima (eds), How universities promote economic development (Washington DC: The International Bank for Reconstruction and Development/The World Bank, 2007), pp. 1-2.

11 EL Boyer, Scholarship reconsidered: Priorities of the professoriate (Princeton, NJ: Carnegie Foundation for the Advancement of Teaching, 1990).

12 Used generically to represent the collective of institutions that comprise the university system in a country; in this case, the university system in the Republic of South Africa. 
settlement of white colonialists in the Cape dating back to the $15^{\text {th }}$ century."13 It was therefore logical that, as the white colonialists expanded their sphere of influence inland, so did the establishment of universities spread inland in order to cater for other races, as well as to produce a white elite to service the emerging industrial complex that was largely fuelled by the discovery of extensive mineral deposits inland. To this end, "the South African Native College was established by missionaries in 1916 and became known as the University of Fort Hare in 1951. The School of Mines, established in Johannesburg in 1895, became the University of the Witwatersrand in 1922."14 It is worth noting that UNISA - as a federal university serving the territory that is modern-day South Africa - was instrumental in the development of universities in South Africa, because it had a number of university colleges. "Over the 30 years following 1930, many of these colleges became full-fledged universities (including the Universities of Pretoria, Potchefstroom, Natal and the Free State)." ${ }^{15}$ It is important to document that the expansion of universities in South Africa was largely aligned to imperial, colonial and racial ethics since the founding of these institutions and for the better part of the $20^{\text {th }}$ century. Oftentimes, these ethics were enforced through legislation - as a bulwark to legitimise policy and programme interventions in the higher education sector of the time. It is for this reason that, "the Extension of University Education Act (passed in 1959) was designed to bar the entry of black students into historically white institutions (HWls) and to establish racially segregated universities. The Universities of Durban-Westville, the Western Cape, Zululand, and the North came into existence shortly afterwards." ${ }^{16}$ With the legislative tools in place and the segregation project at its zenith, other universities established during the period from the mid-1960s to the mid-1980s included the University of Port Elizabeth, the Rand Afrikaans University, the Medical University of Southern Africa and Vista University. By the early 1960s, South Africa's universities were catering to about 62000 students, only 5000 of whom were not white. This racial disparity began to decrease when, in the heyday of separate development in the 1970s and 1980s, universities were constructed in the so-called "independent homelands" of Transkei, Ciskei, Venda and Bophuthatswana. ${ }^{17}$

The foregoing account of the evolution of universities in South Africa finds corroboration in an account by Thiven Reddy, who documents about a differentiated higher education in South Africa whose, "provision evolved and reproduced itself along racial and ethnic lines, prompted in large measure by deliberate state policy", as well as whose, "emergence, roles, and cultures of

13 CT Sehoole, "South Africa". In: JJF Forest and PG Altbach (eds), International handbook of higher education (Dordrecht: Springer, 2007), pp. 972-973.

14 Ibid., p. 973.

15 Ibid.

16 Ibid.

17 Ibid. 
universities in contemporary South Africa relate quite directly to the history of white political, economic and cultural domination and consequently higher education reflects the history of unequal relations of power perpetuated during colonial and Apartheid rule."18 After observing that, "in South Africa during the initial decades of colonial rule the state refused to provide education to blacks", ${ }^{19}$ Reddy echoes the preceding account by Sehoole by documenting that, "instead of denying university education to blacks by relying on the admissions policies of the established white universities, the apartheid state embarked on a determined policy to create universities for the variously state defined ethnically classified black groups. These new universities, the 'bush colleges', were designed to serve as valuable instruments in the over-arching 'grand apartheid' political project, based on the creation of pseudo-independent states in the African 'tribal reserves'." 20 To actualise this project, "for the Zulu and Swazi speakers the government created the University of Zululand. The University of the North was created for Sotho, Tswana, Venda, Tsonga speakers and the Transvaal Ndebele. The universities of the Western Cape and Durban-Westville were created for those classified Coloureds and Indians by the state. By the early 1970s universities were established in the Transkei, Bophuthatswana, and Venda Bantustans." 21 In an insight that directly relates to the current discussion, Reddy notes that, "these institutions were expected to legitimate, reproduce, and constitute, especially among the elites, identities and social relations of race and ethnicity. If successful, this project would divide the black majority into many minorities, weakening both the physical majority and the political, moral argument for democratic majority rule in an undivided South Africa." ${ }^{22}$ In what comes across as a stinging rebuke to neoliberal elites within the South African higher education sector - who often advance the false narrative of seamless integration of the black person into what is essentially a seriously differentiated system and who in the main are to be found in the so-called English universities - as well as a pointer to the role of language in universities in South Africa through time, Reddy documents that, "notwithstanding the verbal claims of administrators at the English language universities to have opposed Apartheid policies, the application of racially restrictive admissions criteria established by state policy and vigilantly policed at university level helped produce universities for Whites, Africans (divided into separate language groups), Indians, and Coloured."23

\footnotetext{
18 T Reddy, Higher education and social transformation: South Africa case study (Pretoria: Council on Higher Education, 2004), p. 9.

19 Ibid., p. 10.

20 Ibid.

21 Ibid.

22 Ibid., pp. 10-11.

23 Ibid., p. 11.
} 
It is worth noting that language has played a key role in ethnic and racial profiling of universities as outlined above. As is observed, "the link between university education in South Africa and the politics of race and ethnicity as perpetuated by a succession of colonialism and Apartheid ensured that over several centuries, university education in South Africa was an exclusive enterprise. In this dynamic, language has been a central catalytic force for several reasons. Fundamentally, the Eurocentric idea of the analogous relationship between language and nation was a core concept in the construction of the colonial and Apartheid ethic. South African universities were founded on this warped and tenuous idea." ${ }^{4}$ It is further documented that, "it is for this reason that there were English universities for the 'English nation' in South Africa and Afrikaans universities for the 'Afrikaner nation' in South Africa". In a pointed critique of the imperial and colonial ethic that informed the establishment of universities in South Africa, it is also pointed out that, "however, the warped and tenuous nature of this idea - analogous relationship between language and nation - becomes exposed when the language question is extended to the logic behind the establishment of universities for the 'Black nation', 'Coloured nation' and 'Indian nation' in South Africa. Rather than following through with the logic of the analogous relation between language and nation in the establishment of universities for these latter nations within South Africa - a logic that could have seen the so-called universities for the Black nation operating in a myriad of indigenous languages, universities for the Coloured nation operating in a different form of Afrikaans and universities for the Indian nation operating possibly in Hindi - the colonial and Apartheid establishment sought to impose their language(s) on the university systems of these nations, thereby undermining the very logic of having designated English and Afrikaans universities." 25 In summing up this critique, it is opined that, "effectively, language was used as a double-edged sword: first, as an easy excuse to perpetuate exclusion to arguably the best universities in the country; and second, as a tool to extend cultural domination over the Black, Coloured and Indian nations in South Africa."26

Over the life of the institution that has come to be known as "the university" in South Africa, therefore, language generally and language politics specifically, have been integral to the evolution of the institutional identities of these hallowed institutions, as well as being a kind of umbilical cord - figuratively speaking - that has tied these institutions to the tapestry of societal socio-political and economic dynamics; and in some instances, societal cultural dynamics as well. Therefore, it can be posited that language politics, defined as, "the micro and macro factors that

24 M Mwaniki, "Language and social justice in South Africa's higher education: insights from a South African university", Language and Education 26(3), 2012, p. 222. Ibid.

26 Ibid. 
are at play in debates about the status and function of language" 27 have been, and remain one of the surest barometers of the intersection between broader societal dynamics and institutional dynamics attendant to universities in South Africa. In line with this observation, a fundamental argument advanced in this article is that institutional dynamics attendant to universities - including language politics as defined - are often and largely a microcosm of the broader societal dynamics, be these socio-political and economic dynamics, amongst others. Bronwyn Louise Strydom corroborates this view. "The university is undoubtedly a social as much as an intellectual institution. As a component of society, involved in constant exchange with society, a university['s] [history] can thus be seen as a constituent of the social history of a society within wider currents of history. It is therefore imperative that it should not be written in isolation. As institutions which are units of larger organisational and cultural networks, the university cannot be studied as an autonomous or independent entity." ${ }^{28}$

In elaborating the foregoing arguments, the discussion in the rest of the article is presented in six parts. The next part is a brief outline of the approach and method used in the research reported in the article. Part three presents a brief overview of the socio-political and economic history of the Free State Province for the duration the UFS has been in existence, with an aim of showing how the evolution of the institutional identity of the university has been closely aligned to this history. Part four presents a tour d'horizon of the concept language politics, with a specific focus on illustrating the inextricable relationships between the evolution of nation-states in the modern era and language politics and key societal institutions within nation-states, such as universities. Part five outlines "linguistic culture", "curriculum as institution" and "critical junctures" as the theoretical scaffolding used for the research reported in the article. Part six plays an integrative role in the article by detailing critical junctures in the UFS's language politics, and the resultant curriculum as institution and linguistic culture. Part seven revisits the fundamental argument advanced in the article, namely that language politics at the UFS have been, and continue to be, a microcosm of the socio-political and economic struggles in the Free State Province through time. This part also presents the conclusions.

\section{NOTE ON APPROACH AND METHOD}

The overarching approach adopted in the research reported in the article is one of history of universities as a genre. However, as Strydom, ${ }^{29}$ citing Rothblatt cautions, "the history of universities has always been a restless genre, a

27 LA Abdelhay, B Makoni and SB Makoni, "Naivasha language policy: The language of politics and the politics of language in the Sudan", Language Policy 10(1), 2011, p. 2.

28 Strydom, p. 15.

29 Ibid., p. 7. 
subfield whose focus is mercurial and whose loyalty to a single discipline is suspect." ${ }^{30}$ It is important to unpack this statement because it captures the core of the approach used in the research reported in this article. Notions of "restlessness" underscored the researcher's continuous quest to reconstruct the language politics of the UFS through time, while seeking to demonstrate that these language politics have not been tandem se, but rather have been part of a larger tapestry of socio-political, economic and sometimes cultural dynamics in the Free State Province and in South Africa. The intriguing aspect is that far from the research reported in this article assuaging the researcher's sense of "restlessness", it only whetted the researcher's intellectual curiosity to further explore this genre of history, while relating insights thereof to the researcher's ongoing investigation into the sociology and politics of university language policies. To say that the focus of history of universities is "mercurial" is to understate what sincerely surfaces when a researcher engages in an investigation of the history of a university. While noting that the university space is one characterised by convergences of contestations and interests, the turns that a history of a university takes could be - and often is - as sudden and unpredictable as the actors inside and outside a university in as much as statute and traditions often manage to create a somewhat false sense of stability around these institutions. It is a moot point to countenance characterising the research reported in this article as exhibiting fidelity to any single discipline. It is at once transdisciplinary, crossdisciplinary and multidisciplinary. In sum, the approach adopted in the research reported in this article finds resonance in the words of Strydom that, "as a genre which includes multiple possible dimensions, university history may add significantly to the understanding of a certain period by considering the university in its social context. This approach goes further than 'traditional' university histories by offering a critical look at the complexities existing in the relationship between the university and the society in which it operated." 31

Literature review was the key method used in the research reported in this article. This was undertaken to, "put the research study at hand into perspective, to determine what previous scholars have written on the topic as well as to identify the main models and theories that are relevant to the research study". ${ }^{32}$ As already intimated in the introduction, this review of literature brought to the fore not only the paucity of historiography of sociology and politics of university language policies in (South) Africa, but also a rather disturbing revisionist historical streak that wrongly ascribes Europe as the birthplace of the university. This first phase of review of the literature was, however, fundamental in defining

30 S Rothblatt, "The writing of university history at the end of another century", Oxford Review of Education 23(2), 1997, p.151.

31 Strydom, p. 29.

32 G-M Howard, "The literature review". In: F Du Plooy-Cillers, C Davis and R-M Bezuidenhout (eds), Research matters (Lansdowne, Cape Town: Juta \& Company Ltd, 2014), p. 101. 
the research problem tackled in the research reported in the article, because it pointed to the hiatus in the research and scholarship on the history of universities and historiography of sociology and politics of university language policies in (South) Africa. The second phase of literature review focused on history of universities as a genre; an overview of the socio-political and economic history of the Free State Province for the period that the UFS has been in existence; core arguments on what constitutes "language politics" and curriculum as institution; linguistic culture and critical junctures as adequate theoretical constructs to interrogate the research problem; and an identification of the critical junctures in the UFS's language politics. In sum, the literature review sought to satisfy the parameters as, "why conduct a literature review"33 as eloquently espoused by Zorn and Campbell that, "first, literature reviews are indeed important for scholarly research within the university setting. They can be a source of ideas, research questions, and hunches to explore. That is, through finding exemplars of well-executed research, interesting ideas that are not particularly well executed, or gaps in the body of knowledge in a discipline, we can identify possibilities for future research. Literature reviews also help scholars avoid 'reinventing the wheel' by enabling them to build on what others have done. Finally, literature reviews help researchers develop an argument for their study by demonstrating that they are extending existing knowledge - building on what is already out there and filling gaps that exist." ${ }^{4}$

With the literature reviews in place, the researcher's task shifted into integrating the somewhat disparate reviews in order to address the research problem. This required the researcher to integrate various aspects of the reviews. This final step involved two closely related techniques. The first was coding - in its open, axial, and selective dimensions - in the sense espoused by Strauss and Corbin. ${ }^{35}$ From this perspective, "coding aims at identifying and defining concept. Concepts are essential because by the very act of naming phenomena, it is possible to examine them comparatively and to ask questions about them. Such questions not only enable researchers to systematically specify what they encounter, but when they take the form of hypothesis or propositions, they suggest how phenomena might possibly be related to each other." ${ }^{36}$ This process confirmed an assertion already outlined that, "the university is undoubtedly a social as much as an intellectual institution. As a component of society, involved in constant exchange with society, a university['s] [history] can thus be seen as a constituent of the social history of a society within

33 T Zorn and N Campbell, "Improving the writing of literature reviews through a literature integration exercise", Business Communication Quarterly 69(2), 2006, p. 173.

34 Ibid.

35 AL Strauss and J Corbin, Basics of qualitative research: Techniques and procedures for developing grounded theory (Thousand Oaks, CA: Sage, 1998).

Ibid., p. 101. 
wider currents of history. It is therefore imperative that it should not be written in isolation. As institutions which are units of larger organisational and cultural networks, the university cannot be studied as an autonomous or independent entity." ${ }^{\prime 37}$ The second was the narrative technique, especially the reflexive aspect of narration, which allows researchers, "the use of theoretical frameworks that shed light on experiences anchored in wider historical, political, social, economic or academic configurations". ${ }^{38}$ The researcher hopes that the final research artefact - this article - meets the threshold of methodological rigour of reflexive narratives which, "arises out of the processes of telling a story or selecting and citing relevant critical incidents in life experiences that are capable of generating new knowledge and practices". ${ }^{39}$ The "critical incidents in life experiences" in the research reported in the article are the critical junctures in the UFS's language politics through time, as reconstructed by the researcher, whereas the "new knowledge and practices" would be the synthesis emanating from the research reported in this article, which points to the materiality of language politics as barometers of not only institutional curriculum and identity, but also societal socio-political and economic struggles.

\section{AN OVERVIEW OF THE SOCIO-POLITICAL AND ECONOMIC HISTORY OF THE FREE STATE PROVINCE FOR THE PERIOD THE UFS HAS BEEN IN EXISTENCE}

Any worthy attempt at reconstruction of the socio-political and economic history of the Free State Province for the period that the UFS has been in existence has to, arguably, start with documenting that the UFS was established in the years that figuratively were the ashes of the Anglo-Boer War (1899-1902) and - figuratively again - in the years that were the embers of the establishment of the Union of South Africa in 1910. By being established in 1904, these two events would shape the historical development of this institution whose main campus is a picturesque piece of high-end real estate on the western fridges of the Bloemfontein Central Business District (CBD), for the next century and beyond. Specifically, by the time the UFS was established in 1904, the territory that used to be known as the "Orange Free State' 40 had been annexed by the

37 Ibid., p. 27.

38 M Maodzwa-Taruvinga and JJ Divala, "Experiences of black women teacher educators in the South African higher education system", South African Journal of Higher Education 28(6), 2014, p. 1963.

39 Ibid.

40 The "Orange Free State" was an independent sovereign Boer Republic in Southern Africa from 1854 to 1902. It came into being with the signing of the Orange River Convention on 23 February 1854 and it was dissolved with the signing of the Treaty of Vereeniging on 31 March 1902. 
British and renamed the "Orange River Colony" 41 under the British Monarch, with Governor Viscount Milner as Head of Government and Commander-inChief. From this perspective, two sets of dynamics largely determined the socio-political and economic dynamics of the Free State Province at the time the UFS was established. The first set of dynamics related to British imperial consolidation. The second set of dynamics related to the strategic repositioning of the Afrikaners in the socio-political and economic complexities of the new order - firstly in the new colony and, after 1910, in the Union of South Africa and its successor republic. ${ }^{42}$ The net result of these twin dynamics was wanton alienation of Africans from their land - a key plank in the African socio-economic and cultural universe and concomitant social fabric implications - through a succession of ethno-racist colonial and apartheid governments.

Colin Murray, writing on land, class and power in the eastern Orange Free State of the 1880s to 1980 s, captures the gist of the two sets of dynamics outlined above by documenting that, "the political economy of the rural highveld of South Africa in the late nineteenth and the twentieth centuries" 43 - a region that incorporates the present-day Free State and Gauteng Provinces and the surrounding rim, incorporating western Lesotho and parts of the Eastern Cape, the Northern Cape, North West, Limpopo and Mpumalanga Provinces - was characterised by the reality where, "Africans were dispossessed of most of their land, in this case more by the pen than by the gun. The countryside was ravaged by one of Lord Milner's lofty imperial visions, and then repaired by another. White farmers were launched by a 'progressive' state on a trajectory of capital accumulation. Black peasants' livelihoods were destroyed by that same racist state. Under mounting structural pressure, exacerbated by the great depression of the 1930s, Africans became immigrants in town or labour tenants and wage labourers in white-owned countryside." 44 The dispossession of land for

41 The "Orange River Colony" came into existence when the British overran the independent 'Orange Free State' in the Anglo-Boer War. However, formally, the colony came into existence after the ratification of the Treaty of Vereeniging on 31 March 1902. It is instructive that Lord Milner is largely accredited with pursuing a punitive Anglicisation policy, which in turn is adjudged as giving rise to, "what eventually became among white Afrikaans-speaking people a rabid, racist and narrow ethnic chauvinism, based essentially on shared language, religious orientation and alleged descent". See, $\mathrm{N}$ Alexander, Language education policy, national and sub-national identities in South Africa (Strasbourg: Council of Europe, 2003), p. 8. The detailed discussion of this is under section 7.

42 The Union of South Africa was dissolved on 31 May 1961 when a new constitution came into force and ushered in a republic. The republic replaced the constitutional monarchy dispensation that was in force during the Union of South Africa period.

43 C Murray, Black mountain: Land, class and power in the eastern Orange Free State 1880s-1980s (Edinburg and Johannesburg: Edinburg University Press and Witwatersrand University Press, 1992), p. 9.

Ibid. 
the Africans created specifically designated areas that came to be pejoratively known as African Reserves. Colin Murray documents that as the process of capital accumulation by white farmers was underway, "in the African reserves, meanwhile, from the 1940s onwards, the central state intervened heavily in the rural economy and imposed an oppressive bureaucratic superstructure. The apartheid regime tightened in the 1950s, a surge of capital intensification swept across white farms in the 1960s, and hundreds of thousands of people were removed to Bantustans in the following decades. These became places of hunger and over-crowding and joblessness and vicious inter-ethnic strife. In myriad ways, resistance to the machinations of the central state was inverted and displaced. Popular anger was turned against the Bantustans autocracies. In the 1980s, particularly, it was also turned against black local authorities in 'white' South Africa. They were rickety structures of municipal oppression set up by Pretoria in the name of limited black self-government outside the Bantustans." 45 The cumulative socio-political and economic quagmire created by these almost century-long systemic disruptions of socio-political and economic order was that, "at the end of 1990, with the emergence of a 'new' South Africa in prospect, it [was] clear that the formal rigidities of racial discrimination [had] shifted to a significant degree. It [was] equally clear that the underlying structural problems of extreme inequality, intractable violence and acute poverty and unemployment will not swiftly dissolve." ${ }^{46}$ This latter observation explains why into the third decade of democracy, the socio-political and economic arrangements created by colonialism, segregation and apartheid in the Free State Province and South Africa continue to persist. In sum, "the social and economic history of modern South Africa has been one of unequal distribution of power" 47 in which, "the structuring forces of colonialism, imperialism, and white political and economic domination [...] deprived indigenous people of their land, and reduced them to different forms of unfree labour" 48 through institutionalised racial capitalism. However, "during the last 20 years of Afrikaner political hegemony (1974-94), a crisis developed surrounding the legitimacy and sustainability of white political supremacy and the profitability of racial capitalism. In the early 1990s, Afrikaner political hegemony collapsed rather dramatically as a prelude to the rise of African political hegemony". ${ }^{49}$ The socio-political and economic foundation of African political hegemony that has been instituted since the democratic transition of the early 1990s to the present is known as "democratic capitalism". According to Terreblanche, "democratic capitalism

\footnotetext{
45 Ibid., pp. 9-10.

46 Ibid., p. 10.

47 S Terreblanche, A history of inequality in South Africa: 1652-2002 (Scottsville and Sandton: University of Natal Press and KMM Review Publishing Company Pty Ltd, 2002), p. 14. Ibid.

49 Ibid., p. 15.
} 
is a dual politico-economic system that reached maturity, after centuries of organised development, in the first half of the $20^{\text {th }}$ century, notably in developed Western democracies. The 'logic' of democracy and capitalism are contradictory: while democracy emphasises joint interests, equality, and common loyalties, capitalism is based on self-seeking inequality and conflicting individual and group interests. The legal system that protects both democracy and capitalism is based on the principle of equality before the law, but maintains inequalities in the distribution of property rights and opportunities in the capitalist system. The 'logic' of capitalism - given the unequal freedoms and unequal rights upon which it is based - thus goes against the grain of the 'logic' of democracy." ${ }^{50}$ For the period under review, education generally, and higher education specifically, has been integral to the entrenchment of systems institutionalising racial capitalism and democratic capitalism through the elaboration and reproduction of norms, ideologies, knowledge, skills, innovations and aptitudes. Given the longevity the system of institutionalised racial capitalism was in force, educational institutions in South Africa, especially those such as the UFS which were meant to cater for the white racial minority, still exhibit vestiges from this system. This perspective also helps in explaining why these institutions seem to be struggling with the transition to elaborate the core tenets of democratic capitalism based on an ideology of social democracy. ${ }^{51}$

From the foregoing it can be advanced that at the heart of the socio-political and economic history of the Free State Province, for the period that the UFS has been in existence, has been an ethno-racial categorisation and differentiation of the citizens of the province. This ethno-racial categorisation and differentiation coalesced around the construct of "language". Neville Alexander succinctly captures this conflation of ethnic, racial and linguistic constructs on the part of the Afrikaner - the dominant ethno-racial group in the Free State Province for the better part of the time the UFS has been in existence - by documenting that, "language became the issue around which the ethnic consciousness of what in effect came to be 'the Afrikaner community', i.e. white Afrikaans-speaking South Africans, crystallised. The fact that the struggle for the recognition of their language as an official language equal in status to English in the new dominion of the Union of South Africa was closely related to the struggle for 'their' land

$50 \quad$ Ibid., p. 16.

51 In a country that "boasts" one of the highest Gini-Coefficient in the world (ranging between 0,66 and 0,69 depending the variables used to measure inequality), South Africa can ill afford the prevalent situation of conspicuous consumption by a minority of the population while the majority live in destitution. Effectively, the issue of social security and concomitant social safety nets is not a polemical luxury for South Africa, but a policy and programme imperative. A tested way to valorize value of investments in social security aimed at creating durable social safety nets is to invest in education generally and higher education specifically - with the latter being geared towards innovations and entrepreneurship for job creation. 
and the independence of the republics they had lost and in which, among other things, gold and diamond deposits had been found, gave rise to a habitus in which certain 'white' varieties of the Afrikaans language featured as one of the criteria for being Afrikaner." 52 Like the land in the foregoing quotation, and as will become apparent later in the discussion, the quest and struggle for control of the UFS as an institution they could call "their" own became over time a near essentialist existential preoccupation. It would therefore not be an observation given to hyperbole were one to posit that the socio-political and economic history of the Free State Province for the period that the UFS has been in existence is inextricably intertwined with the language politics of the province over this period of time on the one part, and that this brand of language politics found expression and manifestation in the institutional culture and curriculum of the UFS as arguably the "most prestigious" higher education institution in the province over this period of time, on the other. The special place of "language politics" in the socio-political and economic history of the Free State Province generally, and the UFS's institutional culture and curriculum, becomes clearer after the discussion of the following three sections. However, suffice to make a preliminary observation that language as a marker of ethno-racial categories has been a key stock in the marketplace of colonialism, segregation and apartheid in the years before the democratic transition in South Africa, and a key stock in the marketplace of rabid exclusionary entitlement and preservation of residual benefits ${ }^{53}$ in the South African post democratic transition. Afrikaans, "a language developed on the back of the now proven tenuous Eurocentric notion of the analogous relationship between ethno linguistic identity, the nation state and a rigorous racial colonial ethic, has been integral to the discursive construction and sustenance of Afrikaner identity; an identity constructed as an apex identity

\section{Alexander, p. 8.}

53 See Terreblanche, p. 5. In particular, Sampie Terreblanche makes the following observation that captures the notion of stock in the marketplace of colonialism, segregation, apartheid and entitlement in post democratic South Africa, "Many whites (especially younger people) are inclined to say that they themselves did nothing wrong, and can therefore not be blamed for the effects of white domination and apartheid. However, they clearly do not understand the systemic character of colonialism, segregation, and apartheid, and their collective responsibility for what has happened. Those who are not prepared to acknowledge the evils of white domination, and accept responsibility for apartheid's residues, are usually adamant that the large-scale 'benefits' (broadly defined) that accumulated in their hands and in those of their parents and grandparents during the extended period of colonialism belong to them and them alone. But what these whites fail to realise is that these 'benefits' are 'contaminated', because they were largely accumulated by means of systemic exploitation. It is rather hypocritical of whites to claim these benefits with greedy self-righteousness but decline any responsibility (directly or indirectly) for the evil of colonialism and its ugly consequences." 
atop of the socio-cultural, political and economic arrangements in South Africa" 54 has been a key currency ${ }^{55}$ underlying the value of stock in the marketplace under reference. A key mechanism of valorising this stock has been languageexclusive higher education institutions - of which the UFS has been such an institution in the Free State Province for more than a century - and the language politics attendant to these institutions. To provide perspective to this observation, the next section provides an overview of language politics.

\section{LANGUAGE POLITICS: TOUR D'HORIZON OF THE CONCEPT}

Language politics are integral to human civilisation - from the beginning to the present and, one can venture to declare, well into the future. The inextricability of language and politics derives, to a large extent, from the centrality and pervasiveness of language in all aspects of human endeavour and humanity's constant preoccupation with power, organisation, control, cultural (re)production and self-preservation. In the odyssey of evolution, humans discovered quite early on that their ability to deploy language for the ends of the preoccupations just

54 M Mwaniki, "Chasing a phantom: Afrikaans in higher education in the globalisation era". In: CSK Chua (ed.), Un(intended) language planning in a globalizing world: Multiple levels of players at work (Warsaw: De Gruyter Open, 2017), p. 184.

55 In the eloquent sense outlined by KS Dhir, "The value of language: concept, perspectives, and policies", Corporate Communications: An International Journal 10(4), 2005, p. 364 that, "Economists typically emphasize three functions of currency: (1) a unit of exchange; (2) a unit of account; and (3) a store of value. As a unit of account, it is used in invoicing trade and in denominating financial instruments. As a medium of exchange, it is used to settle trade and financial transactions. As a store of value, it serves as an investment asset. In corporate or community settings, a language, too, may be seen as performing three analogous functions of: (1) exchanging information and knowledge; (2) accounting through narratives; and (3) storing value of knowledge and know-how. In different economic communities, different currency may be used to transact money. Similarly, in different social communities, different language[s] may be deployed to communicate or transact ideas. The value of a currency to an organization operating in an economic environment may be affected by such considerations as the demographic range in which the currency is used, the degree of investment made in that currency by the economic community, general demand for the currency, and so on. Similarly, the value of a language to an organization may be affected by the degree to which the language is used in the demographic community defining the organisation's strategic environment, the investment in the language relative to other available languages, demand for the language as a commodity within the organisation's strategic community, and so on. Just as different prevailing economic trends have implications for strategies devised for the management of currencies held by a company, different social trends have implications for the management of a corporation's language assets." With regard to the subject matter under discussion, "corporation", "organisation" would refer to the UFS. 
listed was probably as vital and critical as their ability to walk and run upright. ${ }^{56}$ As human societies became more complex, the appreciation of the critical role of language in processes through which decisions that affect members of a (speech) community are made grew exponentially. This realisation, although difficult, if not impossible, to ascribe a specific date to when it could have possibly happened, marked the drifting of language politics from a peripheral, if not fridge, human pastime into the centre of humans' almost absolute and constant preoccupation with power, organisation, control, cultural (re)production and self-preservation. This development was premised on a fundamental shift from language being perceived as, "dynamic and open to a set consisting of rules and regulations of how people should speak and write". ${ }^{57}$ In a view that corroborates the foregoing, Shohamy documents that, "a variety of historical developments were instrumental in perpetuating the concepts of viewing language as a closed system. Two main developments took place at the end of the nineteenth century and they perpetuated each other. The first was the emergence and formation of nation-states as the dominating political unit, especially in Europe as well as in the colonies, which were dominated by the European nations. The second was the emergence of descriptive linguistics, which was developed by anthropologist linguists, whose goals were to provide analytic descriptions of languages and the ways they are used. These very descriptions of how languages are used turned with time into a set of stagnated rules and laws governing how languages should be used within the political framework of the nation-states." ${ }^{58}$ Language became a major tool in the political apparatus of the nation-state, thus marking the incipient origins of language politics as they are known today. It is important, however, to document an interesting perspective into what language politics entail, namely that, "language politics [are] the politics of threatened identity" by means of which "the titular group defines its identity primarily in terms of its distinct language, amount[ing] to saying that the survival of the group itself is at stake". ${ }^{59}$ Key instruments in the consolidation and perpetuation of language politics so defined, are language policies and the ideologies generated by them. ${ }^{60}$ Little wonder then that the Afrikaner have been at the forefront of the discourses that have developed and consolidated language politics in South(ern) Africa for the better part of the last three centuries, in general, and institutional language politics of the UFS, specifically, for the period that the institution has been in

56 See T Noakes (with M Vlismas), Challenging beliefs: Memoirs of a career (Cape Town: Zebra Press, 2012).

57 E Shohamy, Language policy: Hidden agendas and new approaches (London and New York: Routledge, 2006), p. 25.

58 Ibid.

59 D Arel, “Language politics in independent Ukraine: Towards one or two state languages?", Nationalities Papers 23(3), 1995, p. 597.

60 See V Ramanathan, The English-vernacular divide: Postcolonial language politics and practice (Clevedon: Multilingual Matters Ltd, 2005), p. 35. 
existence, because the institution was and is still perceived as a key instrument for the "survival" of Afrikaans as a language. This "survival" is implicitly related to socio-political and economic fortunes of the Afrikaner in relation, and in contrast, to other communities in the province and in the country who are perceived as not only threatening the survival of Afrikaans, but the socio-political and economic fortunes of the Afrikaner. In sum, language politics refers to the entire ambit of discursive practices ${ }^{61}$ and the social practices that they predicate and/or perpetuate that seek to harness and deploy language for the ends of acquisition, retention and (re)production of control and power as well as preservation of group and cultural identity.

It is perhaps important, for clarity purposes and as a way of concluding the discussion in the present section, to situate the elaboration of language politics within a domain in which they are latently manifest, namely, education. It has already been noted that language policies and the ideologies generated by them are the lifeblood of language politics. As such, "language policies and ideologies contribute to implicit and explicit rules that organise human activity and thought, including how students are channelled, in particular, in invisible grooves deemed 'appropriate' by the larger socio-educational apparatus." ${ }^{2}$ It is instructive to note that the emergence of the nation-state with its inextricable relationships to the rise and consolidation of language politics also marked the spread of mass education with the university at the apex of the emergent sociopolitical and economic system that came to be known as public education. It is therefore not coincidental that in many communities the public university - such as the UFS - was and remains the crown jewel at the intersections of sociopolitical and economic dynamics and nationalist aspirations during much of the last century and in national aspirations at the closing years of the last century and the opening years of the current century.

\section{LINGUSTIC CULTURE, CURRICULUM AS INSTITUTION AND CRITICAL JUNCTURES AS THEORETICAL SCAFFOLDING}

In as much as the closing decades of the last century, as well as the opening decades of the current one, has witnessed a peculiar drift in social science

61 In the sense outlined by M Foucault, "History of systems of thought: Summary of a course given at Collège de France - 1970-1971". In: DF Bouchard (ed.), Language, countermemory, practice: Selected essays and interviews by Michel Foucault (Ithaca, New York: Cornell University Press, 1970/71), p. 200 that, "discursive practices are not purely and simply ways of producing discourse. They are embodied in technical processes, in institutions, in patterns of general behaviour, in forms for transmission and diffusion, and in pedagogical forms which, at once, impose and maintain them."

Ramathan, p. 35. 
research - especially in the global South - that seeks to undermine the primacy of theory, it is important to reassert the primacy of theory in social science research. Theory is fundamental. This is because, "the legitimacy of a scholarly field is linked to the quality of the theories that explain and predict the phenomenon of interest in that field and the social relevance of the theories and findings". ${ }^{63}$ In social science research - due to the [complex] nature of the phenomena under interrogation - recourse is often to borrow and integrate theories from different disciplines and domains with a view to engender $a$, "greater understanding of, as well as creating opportunities to support, refine and extend, the source theory". ${ }^{64}$ These observations apply to the research reported in this article, especially in light of the opening statements. In effect, the research reported in this article borrowed and integrated three theoretical orientations, namely linguistic culture, curriculum as institution and critical junctures in an attempt to explain how language politics at the UFS have been, and are a microcosm of the socio-political and economic struggles in the Free State Province through time, because of the centrality of the UFS in the socio-political and economic discourses and dynamics of the province. The three theoretical orientations are outlined in the following subsections.

\subsection{Linguistic culture}

Linguistic culture as a theoretical orientation is primarily associated with Harold Schiffman. According to Schiffman, "the sum totality of ideas, values, beliefs, attitudes, prejudices, myths, religious strictures, and all other cultural 'baggage' that speakers bring to their dealings with language from their culture. Linguistic culture is also concerned with the transmission and codification of language and has a bearing also on the culture's notions of the value of literacy and the sanctity of texts [...] It is important to view language policy as not only the explicit, written, overt de jure, official, and 'top-down' decision-making about language, but also the implicit, unwritten, covert, de facto, grassroots, and unofficial ideas and assumptions, which can influence outcomes of policy making just as emphatically and definitively as the more explicit decisions." ${ }^{65}$ In light of the core argument in the article, the important generalizable proposition deriving from the exposition of "linguistic culture" is that, almost without exception, there is a dialectic relationship between an institution's language politics and the socio-political and economic dynamics of the society in which an institution is domiciled.

$63 \mathrm{H}$ Haugh, "The importance of theory in social enterprise research", Social Enterprise Journal 8(1), 2012, p. 7.

64 Ibid., p. 10.

65 H Schiffman, "Language policy and linguistic culture". In: T Ricento (ed.), An introduction to language policy: Theory and method (Malden and Carlton: Blackwell Publishing Ltd, 2006), p. 112. 
Mwaniki - Language politics and the struggle for the soul of the University of the Free State

\subsection{Curriculum as institution}

A leading theorist on curriculum as institution is Jonathan Jansen. ${ }^{66}$ Much of the insights in this section derive from Jansen's work. In an insight that sets the background into expounding the theoretical precepts of curriculum as institution, Jansen documents that, "at an academically conservative institution, for students and staff alike, curriculum change is painful, and in some instances, impossible. Ironically, the institutional curriculum is more powerful than the documented curriculum and calls for a deeper look into what lies at the foundations of the former. The institutional curriculum appears to be embedded at the level of 'blood knowledge', which refers to the emotional, psychic, social, economic, political and psychological inheritance of an institution and wider community." ${ }^{67}$ The UFS is such an institution. In such an institution, the curriculum therefore embodies more in the sense of, "regarding the curriculum not only as a text inscribed in the course syllabus for a particular qualification, but an understanding of knowledge encoded in the dominant beliefs, values and behaviours deeply embedded in all aspects of institutional life. Knowledge therefore becomes not only what is formally designated for learning, such as in the course syllabus, but what is widely understood within the institution to be acceptable forms of knowledge and recognised ways of knowing that distinguishes one university type (such as the Afrikaans universities) from the rest. To be sure, the course syllabus is an expression of the curriculum as an institution - but it is only one such manifestation of the regnant knowledge dispersed throughout the ceremonies, symbols, rituals, rules, regulations, discourses and countless other cultural transactions within the common-sense of, in this case, the public university." 68

In consolidating the core insights of "curriculum as institution" as a theoretical frame, Jansen documents that, "the curriculum in this view is therefore both tangible (course outlines) and intangible (discursive patterns), but throughout it is 'a shaping force' in the lives of those who teach, learn, administer, manage and lead within an institution. It is the knowledge the administrative clerk learns about who not to offend in an institution, which rules to follow and which to ignore, about the written rules and the unwritten rules, and about how to navigate this embedded script without harm to oneself and to one's career. It is the knowledge the young academic learns about what kinds of postures and positions can advance her career and which behaviours can inhibit promotion or even end a career; such knowledge goes beyond what is written in the administrative guide to promotion for it includes the unspoken

66 Former Dean of the Faculty of Education at the University of Pretoria and Former Vice Chancellor and Rector of the University of the Free State.

67 J Jansen, "The curriculum as an institution in higher education". In: E Bitzer (ed.), Higher education in South Africa: A scholarly look behind the scenes (Stellenbosch: SUN MeDIA, 2009), p. 123.

Ibid., p. 126. 
but obtainable knowledge about how to advance academically within the peculiarities of that institution. Without access to such knowledge, the newcomer is often exposed and disciplined while the old hands can negotiate these hidden rules for behaviour almost instinctively. In all these examples, the curriculum as embedded knowledge, values and beliefs spreads throughout the operational crevices of the institution and transforms the behaviour of campus citizens."69 The "acceptable forms of knowledge", as well as "dominant beliefs, values and behaviours deeply embedded in all aspects of institutional life" that are core motifs in the theoretical precept of "curriculum as institution" largely derive from the dominant cultural group and largely (re)produce its framing of the sociopolitical and economic contestations in the society within which the institution under reference is domiciled. In the case of the UFS, the dominant cultural group in the better part of the lifetime of the university has been the Afrikaner cultural group. With the centrality of "language" in the identity of the Afrikaner cultural group, inevitably therefore, language politics have been at the core of how this cultural group has framed the socio-political and economic contestations within the institution itself and in the Free State Province, if not South Africa. In turn, these contestations, as they have played out within the institution have been a microcosm of the struggles in the province, if not South Africa.

\subsection{Critical junctures}

The last theoretical orientation that informed the research reported in this article is critical junctures. "Critical junctures" as a theoretical construct is mainly associated with the work of Daron Acemoglu ${ }^{70}$ and James A Robinson. ${ }^{71}$ According to Acemoglu and Robinson, critical junctures are, "major events that disrupt the existing political and economic balance in one or many societies". ${ }^{72}$ The authors proceed to document that "once a critical juncture happens, the small differences that matter are the initial institutional differences that put in motion very different responses". ${ }^{73}$ Critical junctures are - without exception precipitated by contestations between and amongst protagonists who, over historical time ${ }^{74}$ have wielded social, political and economic power. Because

69 Ibid., pp. 127-128.

70 Turkish-born American economist who, at the time of writing, is the Elizabeth and James Killian Professor of Economics at the Massachusetts Institute of Technology (MIT).

71 British political scientist and economist who, at the time of writing, is the Dr Richard L Pearson Professor of Global Conflict Studies and University Professor at the Harris School of Public Policy at the University of Chicago.

72 D Acemoglu and JA Robinson, Why nations fail: The origins of power, prosperity and poverty (London: Profile Books Ltd, 2012), p. 431.

73 Ibid., p. 107.

74 In the sense espoused by M Setterfield, "Historical time and economic theory", Review of Political Economy 7(1), 1995, p. 3 that, "in historical time, events occur in a uni-directional sequence. Any event occurring in the present exists in the context of a given and 
of this, "the outcomes of the events during critical junctures are shaped by the weight of history, as existing economic and political institutions shape the balance of power and delineate what is politically feasible. The outcome, however, is not historically predetermined but contingent. The exact path of institutional development during these periods depends on which of the opposing forces will succeed, which groups will be able to form effective coalitions, and which leaders will be able to structure events to their advantage." 75 In the context of the research reported in this article, imperial conquest and colonialism are critical junctures. Others are the institutionalisation of segregation through apartheid and its eventual demise as well as the advent of constitutional democracy.

The question that arises at this point in the discussion is what kind of theoretical scaffolding emerges when the foregoing three theoretical orientations are integrated against the backdrop of what constitutes language politics? The theoretical scaffolding that emerges is at once complex and insightful. The theoretical scaffolding that emerges is that at any point in time, institutional language politics are a reflection - a microcosm - of the linguistic culture of the society in which an institution is embedded generally, and the linguistic culture of the dominant cultural group socio-politically and economically, specifically. Although the discursive practices and social practices that undergird and reproduce institutional language politics are largely dependent upon critical junctures in the society in which an institution is embedded, the curriculum as institution of an institution seems to endure through and beyond critical junctures because of residual "baggage" and policy implementation lags that often accompany policy interventions aimed at aligning institutional curriculum with socio-political and economic realities attendant to critical junctures. Effectively, due to the enduring and entrenched nature of institutional curriculum, only targeted and often disruptive - in the sense of being innovative - interventions can ever align institutional curriculum to critical junctures, if not pre-empt future critical junctures.

Against the background of the foregoing, it is important to pose a final question in relation to the theoretical scaffolding so distilled. This question is whether the theoretical scaffolding so distilled meets the four thresholds by means of which theories must be adjudged, namely descriptive, predictive, explanatory and theoretical adequacy. ${ }^{76}$ The answer to this question is in the affirmative. The scaffolding has descriptive and predictive adequacy because

immutable series of prior events corresponding to the periods which make up the past. In historical time, what is current is so in the context of what has gone before, which draws to our attention the possibility that the unique sequence of prior events leading up to the present might actually matter, in the precise sense that these events may affect current and future outcomes." Ibid.

76 For a detailed discussion, see RL Cooper, Language planning and social change (Cambridge: Cambridge University Press, 1989), pp. 46-98. 
it can represent what happens at the intersections of institutional language politics and institutional curriculum at any critical juncture and forecast what happens thereafter - whether certain interventions are implemented or not. The scaffolding has explanatory adequacy because it allows accounting for particular outcomes, which is to say, the ability to identify the causal or determining factors at the intersections of institutional language politics, institutional curriculum and critical junctures. The scaffolding has theoretical adequacy because its relatively small number of propositions, when taken together, have the ability to explain a relatively wide spectrum of dynamics at the intersections of institutional language politics, institutional curriculum and societal critical junctures.

\section{CRITICAL JUNCTURES IN THE UFS' LANGUAGE POLITICS ${ }^{77}$ AND RESULTANT LINGUISTIC CULTURE AND CURRICULUM AS INSTITUTION}

Four critical junctures that have shaped the UFS' language politics in its lifetime are identifiable. These are elaborated on in the following subsections with an attempt made to document the resultant linguistic culture and curriculum as an institution.

\section{1 $1^{\text {st }}$ Critical juncture: The $1910 \mathrm{~s}$ to the early $1940 \mathrm{~s}$}

The UFS was established as Grey University College (GUC) in 1904 with Dr J Brill as the first Rector. The language medium of the new college was English. However, in 1911, the first subject was taught in Dutch. By 1918, Faculties of Science and Arts were established and GUC became a college of the University of South Africa (UNISA). In the same year, DF Malherbe was appointed as the first Professor in Afrikaans. During the same time, the institution started drifting towards increasingly embracing dual-medium instruction in Afrikaans and English. In line with the rising fortunes of the Afrikaner farming and business community in the Free State Province, the second Rector, JD Kestell, launched a recruitment campaign for financial survival of the nascent college which saw the Free State farming and business community starting to support the GUC. Kestell retired in 1927 and Hofmeyr became the third Rector in 1928. However, GM Hofmeyr's term was short-lived - more of a transition Rectorship - and he was replaced in 1929 by DF Malherbe, who early in 1918 has become the first Afrikaans Professor as the fourth Rector of the GUC. Under the fourth Rector, the

77 It would be remiss not to acknowledge with gratitude the assistance of Prof. Theodorus Du Plessis - Director, Unit for Language Facilitation and Empowerment at the UFS - who gifted me with a copy of the commemorative history of the first 100 years of the University of the Free State - University of the Free State, From Grey to Gold: The first 100 years of the University of the Free State (Paarl: Paarl Print, 2006). Apart from language politics accompanying the $4^{\text {th }}$ Critical Juncture, the rest of the account on language politics at the UFS is reconstructed from this book. 
GUC took a Christian Afrikaans character and the language struggle - designed to replace English with Afrikaans - started in earnest. In 1925, Afrikaans became an official language of the Union of South Africa. In 1934, RB Saayman became the fifth Rector and Registrar of GUC. He intensified the campaign for 50-50 Afrikaans-English bilinguality.

In 1935, GUC was renamed the University College of the Orange Free State (UCOFS) - taking up the name of the erstwhile Boer Republic that had been vanquished by the British during the Anglo-Boer War. Little wonder then that with this onomastic turn of events and change in fortunes, the language struggle intensified with matters coming to a head in 1943 when the Council and SRC clashed over the 50-50 language policy. Evidently, the Council lost out in this "language struggle" because a new Council was constituted in 1944. This first critical juncture coincided with the establishment of the Union of South Africa and the consolidation of Afrikaner socio-political and economic power within the Union of South Africa. This power was, in turn, transposed into the linguistic culture and curriculum as institution of the UFS during this time.

\section{2 $2^{\text {nd }}$ Critical juncture: Late 1940 s to 1950}

The second critical juncture in the UFS' language politics started in the late 1940s. In $1946 \mathrm{H}$ van der Merwe Scholtz was appointed as the sixth Rector of the UCOFS. In the same year - in line with Afrikaner Calvinist theological traditions - it took on a Christian-national character. Little wonder then that in 1948 - coinciding with the National Party coming to power and implementing apartheid - the dual-medium instruction was phased out in favour of Afrikaans only. This critical juncture was consolidated by the University gaining autonomy as the University of the Orange Free State (UOFS) with Van der Merwe Scholtz as the Rector and CR Swart as Chancellor. Again, the second critical juncture coincided with the consolidation of Afrikaner socio-political and economic power within a segregationist Republic in which the Afrikaner was at the apex of sociopolitical and economic arrangements. This power was in turn transposed into the linguistic culture and curriculum as institution of the UFS during this time which were, in turn, a microcosm of the socio-political and economic struggles in the Free State Province - if not the wider South Africa.

\section{3 $3^{\text {rd }}$ Critical juncture: Late 1980 s to the 1993 adoption of the Interim Constitution}

The third critical juncture was ushered in by signs that the banal experiment that was apartheid was about to collapse in spectacular fashion. To align itself to the emergent brave world, the UOFS admitted its first black undergraduates in 1988. In 1989, under the tenth Rector, FP Retief, the institution began initiatives at transformation. In 1990 under JS Stegmann as Chancellor and 
Retief the UFS opened its doors to all races. In 1993 - the year in which the Interim Constitution of the Republic of South Africa was adopted with a language clause that recognised eleven official languages - the University adopted a parallel-medium language policy of Afrikaans and English. The same year saw the first black Council member join the Council of the UFS, while in 1994 the first coloured Council member joined the Council of the UFS. The same year saw the first black member of Senior Management. The changes occasioned by the third critical juncture were again transposed into the linguistic culture and curriculum as institution of the UFS during this time - thus the emergent discourse around "transformation". Whether this discourse was matched with substantive material changes is a matter for further debate that largely lies beyond the ambit of the current discussion. However, again the language politics that were attendant to this critical juncture and the linguistic culture and curriculum as institution that they predicated were a microcosm of the socio-political and economic struggles in the Free State province - if not the wider South Africa - at the time. It was a struggle to shed the shackles of the long night that was imperialism, colonialism and segregation that had scarred the Free State Province and the country for centuries and a guarded optimism to welcome a new dawn of promise and hope.

\section{$6.44^{\text {th }}$ Critical juncture: \#RhodesMustFall student movement and its aftermath}

Direct antecedents of what happened at the UFS during the \#RhodesMustFall movement and its aftermath are traceable to events that happened almost a decade earlier and which highlighted the entrenched segregationist linguistic culture and curriculum as institution at the UFS. Sometimes in 2008 the now infamous racist Reitz video thrust the UFS into international spotlight. Maybe no one captures the crises spawned by the Reitz video incidence better than Donna Bryson. In the words of Bryson, "the Free State's sleepy, provincial university found itself at the centre of an international uproar over a video some of its white students made in 2007 to announce their opposition to racial integration in their hall of residence. The video became public, on the Internet, in early 2008. The students' video showing them humiliating the black women who cleaned their dormitories was viewed worldwide on YouTube and discussed on Facebook, making the UFS an international symbol of the persistence of racism in South Africa. The idea that South Africans studying at the university more than a decade after apartheid's end would go to great lengths to record such sentiments was perhaps as shocking as the video's images of casual racism."78 Fast forward seven years after this tragic event that will forever remain a blot on the institutional history of the UFS and the events around the \#RhodesMustFall student movement will mark the culmination of the critical juncture whose incipient seeds had been sown by the discontent around the Reitz

D Bryson, It's a black and white thing (Cape Town: Tafelberg, 2014), p 11. 
video. Embedded in the \#RhodesMustFall movement was a language-specific hashtag movement namely \#AfrikaansMustFall movement. At the UFS, these two movements occasioned an institution-wide movement to not only review the parallel-medium language policy as the linchpin of the institution's linguistic culture, but also to decolonialise the documented curriculum in the institution as a way of dismantling the deeply embedded curriculum as institution at the UFS. By January 2017 the UFS adopted an English-only language policy that will be implemented in phases over the next three years. By the time of writing, efforts at decolonialising the documented curriculum at the UFS are ongoing. The brand of language politics attendant to this critical juncture and the linguistic culture and curriculum as institution that they are occasioning are a microcosm of the socio-political and economic struggles in the Free State Province - if not the wider South Africa - at present and one dare submit, well into the future. These socio-political and economic struggles are undergirded by a core principle that ethnolinguistic character and attributes cannot and shouldn't be the primary determinants of who gets a decent progressive education and therefore gets a head start at being/becoming productive members of society - in the Free State Province and beyond.

\section{INSTITUTIONAL LANGUAGE POLITICS AT THE UFS AS A MICROCOSM OF SOCIO-POLITICAL AND ECONOMIC STRUGGLES IN THE FREE STATE PROVINCE THROUGH TIME}

The language politics of the UFS which, over the period this institution has been in existence, have largely been shaped and driven by exclusionary socio-political and economic interests on the part of the Afrikaner, can be characterised as essentially a struggle for the soul of the soul of the UFS because the institution has been, and continues to be, a key institution in valorising socio-political and economic interests in the Free State Province and beyond. The institution has been able to do this through a particular brand of language politics that has predicated a particular brand of curriculum as institution. In tandem, the recent shift in language politics, occasioned by the fourth and latest critical juncture, should predicate a shift in curriculum as institution at the UFS. However, it is instructive to document that this latter shift is not historically predetermined but contingent. The exact path that the UFS will take as from this latest critical juncture will depend on which of the opposing forces will succeed, which groups will be able to form effective coalitions, and which leaders will be able to structure events to their advantage. However, what is not in doubt in the aftermath of this latest critical juncture is that its attendant language politics will still be a microcosm of the socio-political and economic struggles in the Free State Province and beyond. 


\section{CONCLUSION}

The chequered history of the UFS as a microcosm of the socio-political and economic struggles in the Free State Province through time notwithstanding, it is probably befitting to characterise the history of the University of the Free State as, "one of faith, hope, struggle and determination"; 79 faith in the promise of world-class progressive education for all citizens of the province, the country, the continent and beyond. Hope, probably of the variety once described by President Barack Obama - audacious hope - which is hope in the face of difficulty, hope in the face of uncertainty, ${ }^{80}$ because in as much as the socio-political and economic fortunes of the Free State Province and South Africa will inevitably follow the cyclic ebbs of the high and silly seasons of provincial and national politics, the UFS will, as it has already demonstrated, endure through them all - well into posterity. Struggle to overcome the, "ethnic, class, social, race, linguistic, [economic] and religious cleavages" 81 that for so long defined the Free State Province and South Africa and created, "several obstacles for the survival [of South Africa] as a liberal democratic state" 82 and which found expression in the language politics and curriculum as institution at the UFS. Determination to not only overcome the burden of its history, but to seize the present and the future to become a beacon of the Free State Province, South African and African aspirations in a decolonialised higher education curriculum with global valence. However, even in that future given the centrality of language [politics] in the evolution of the modern South African state, the research presented in this article gives the author the courage to opine that the language politics at the UFS and to some extent the language politics at other higher education institutions in South Africa - will always be a microcosm of the socio-political and economic struggles in the Free State Province - and beyond. As the research reported in this article has sought to demonstrate, universities in South Africa - and possibly elsewhere - are not immune to the socio-political and economic struggles of the societies in which they are domiciled. Further, in the opinion of the researcher, the way forward in the contestations attendant to language politics in South Africa's higher education is to return to the fidelity of the overarching ideology of South Africa's 1996 Constitution, namely "transformative constitutionalism"

79 Jacket cover of commemorative history of the first 100 years of the University of the Free State - University of the Free State, From Grey to Gold: The first 100 years of the University of the Free State (Paarl: Paarl Print, 2006).

80 Keynote Speech delivered by Barack Obama at the 2004 Democratic National Convention convened from July 26 to 29, 2004 at the TD Garden in Boston, Massachusetts, United States of America.

81 A Venter, "The context of contemporary South African politics". In: A Venter and C Landsberg (eds), Government and politics in the new South Africa ( $3^{\text {rd }}$ edition, Pretoria: Van Schaik Publishers, 2006), p. 3. Ibid. 
especially and specifically as to how this ideology applies to the totality ${ }^{83}$ of the writ of section 29(2) that, "everyone has the right to receive education in the official language or languages of their choice in public educational institutions where that education is reasonably practicable. In order to ensure the effective access to, and implementation of, this right, the state must consider all reasonable educational alternatives, including single medium institutions, taking into account -

a. equity

b. practicability

c. the need to redress the results of past racially discriminatory laws and practices".

Litigation that disingenuously cherry picks this sub-clause in South Africa's Constitution's Bill of Rights in furtherance of narrow ethnolinguistic interests doesn't augur well for the future of language politics in South Africa's (higher) education and the country's social cohesion project. An important consideration for and in future research would therefore be an attempt to interrogate how multilingualism can be engendered in South Africa's (higher) education in light of the above Constitutional injunction without resorting to intellectual disingenuousness in pursuit of the same.

\section{ACKNOWLEDGEMENT AND DISCLAIMER}

This work is based on research supported wholly by the National Research Foundation of South Africa (Grant Number: 115157). The author acknowledges that the opinions, findings, conclusions and recommendations expressed in this publication are that of the author and under no circumstances can the National Research Foundation of South Africa be held liable whatsoever for such opinions, findings, conclusions and recommendations.

83 Deliberate emphasis by the author because in recent litigation around language-ineducation in South Africa, attempts have been made by some litigants to emphasize parts of this sub-clause while neglecting the qualifying caveats that derive from the need to address South Africa's peculiar past of racial discrimination. 